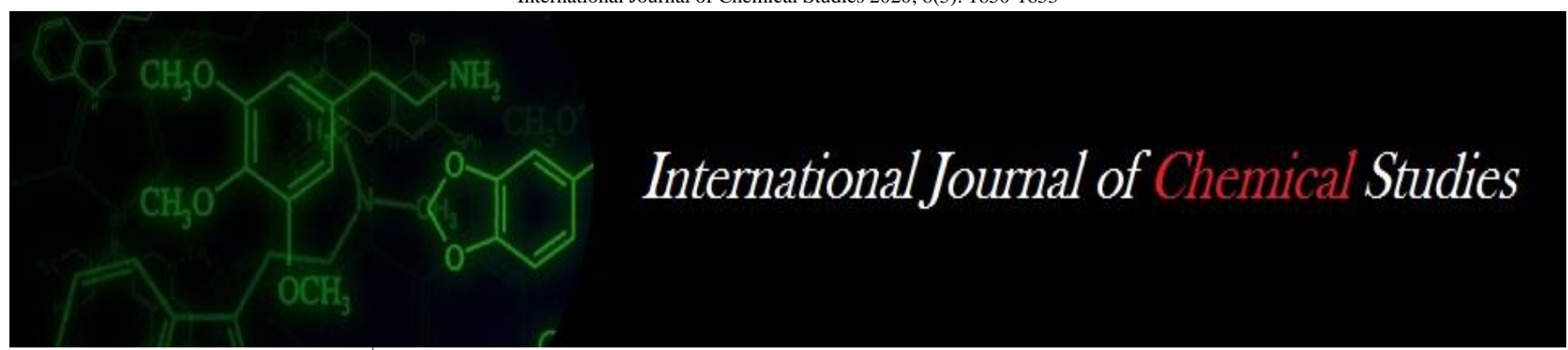

P-ISSN: 2349-8528

E-ISSN: 2321-4902

www.chemijournal.com

IJCS 2020; 8(5): 1850-1853

(C) 2020 IJCS

Received: 25-06-2020

Accepted: 27-08-2020

Sarita Patel

Department of Floriculture and

Landscaping, College of

Agriculture, OUAT,

Bhubaneswar, Odisha, India

Dr. Sashikala Beura

Professor and Head, Department of Floriculture and Landscaping and Director, BTCC, College of Agriculture, OUAT,

Bhubaneswar, Odisha, India

Dr. Lilymoony Tripathy Associate Professor

(Floriculture), College of Horticulture, Chiplima, Odisha, India

Dr. Abhiram Dash

Assistant Professor, Department of Agricultural Statistics, College of Agriculture, OUAT,

Bhubaneswar, Odisha, India

Dr. Geeta Pandey

Assistant Professor, Department of Floriculture and Landscaping, College of Agriculture, OUAT, Bhubaneswar, Odisha, India

Sonali Priyadarshani

Department of Floriculture and

Landscaping, College of

Agriculture, OUAT,

Bhubaneswar, Odisha, India

Mousumi Madhusmita Mishra Department of Floriculture and Landscaping, College of Agriculture, OUAT,

Bhubaneswar, Odisha, India

Corresponding Author: Sarita Patel

Department of Floriculture and

Landscaping, College of

Agriculture, OUAT,

Bhubaneswar, Odisha, India

\section{Effect of different levels of Nanomax (4\% NPK) and Polyfeed (19:19:19 NPK) on Coreopsis tinctoria}

\author{
Sarita Patel, Dr. Sashikala Beura, Dr. Lilymoony Tripathy, Dr. Abhiram \\ Dash, Dr. Geeta Pandey, Sonali Priyadarshani and Mousumi Madhusmita \\ Mishra
}

DOI: https://doi.org/10.22271/chemi.2020.v8.i5y.10571

\begin{abstract}
An experiment entitled "Effect of different levels of Nanomax (4\% NPK) and Polyfeed (19:19:19 NPK) on Coreopsis tinctoria" was conducted at Department of Floriculture and Landscaping, College of Agriculture, Odisha University of Agriculture and Technology, Bhubaneswar, Odisha during 2018-19 and 2019-20. The experiment was laid out in completely randomized design in pots, with 7 treatments and 3 replications. The treatment comprises of 3 levels of Nanomax (4\% NPK) viz. 3,4 and $5 \mathrm{ml} / \mathrm{L} ; 3$ levels of Polyfeed (19:19:19 NPK) viz. 3, 4 and $5 \mathrm{~g} / \mathrm{L}$ and one absolute control with no foliar spray of fertilizers. From the result of 2 year research work it was concluded that the treatment receiving $5 \mathrm{~g} / \mathrm{L}$ of Polyfeed (19:19:19 NPK) showing significant result among the rest of the treatment used with respect to vegetative parameters, flowering parameters and flower quality parameters.
\end{abstract}

Keywords: Nanomax (4\% NPK), polyfeed (19:19:19 NPK), Coreopsis tinctoria

\section{Introduction}

Coreopsis tinctoria is a lesser known annual forb which belongs to family Asteraceae. Its origin is from North America and now it is distributed worldwide. The point of attraction of this flower crop is in its pinnately compound foliage which tapers towards the top of the plant with attractive numerous yellow colour flower having a maroon center and sometime the maroon base is spreads on the surface of the ray florets is seen. Petals are notch tipped and flower heads occurs on long stalks (E. B. Smith and H. M. Parker, 1971) ${ }^{[12]}$. Coreopsis tinctoria is versatile in uses. It produces small but large number of flowers which creates a very attractive mass effect in a garden. It is very much suitable for beds, background boarders, containers, cut flowers etc. This plant attracts butterflies that bring mobility in a garden.

During 1970s the concept of Green Revolution was, more input and more output. The consumption of fertilizers, different agrochemicals increased exponentially from 1970 and is continuing till now. However, the agricultural production has reached a plateau which is severely affecting the farming community.

In 1974, Norio Taniguchi of Tokyo Science University described the word "Nanotechnology". The structure ranges between 1-100 nm are presented by Nano technology. In an inch, there are 25,400,000 nanometers. Around 100,000 nanometers thick is a sheet of newspaper. The matter present at nanoscale are novel and different from those at macroscopic level. Nano particles can pass through the cell wall in plants. This process is done at cellular level so it is more effective than the conventional method.

Nano fertilizers have higher nutrient use efficiency as the particle size is too small, facilitating higher surface area. It can easily penetrate in the cells of plant. Studies says that Nano fertilizers boosted the growth, yield and good quality of crops. Many research says that Nano fertilizers significantly increases the crop yield over control. It is due to the increase in growth of all the plant parts and more photosynthate accumulates resulting in higher yield.

In this era the requirements of balanced fertilization is very much essential for achieving optimum plant growth and development for good yield of quality flowers. The largest potential benefit derived is when foliar nutrient applications are applied at the critical growth stages, 
especially when the nutrient requirement by the shoot is high (Garcia and Hanway 1976, Kanan 1980) ${ }^{[4]}$.

Now specialty fertilizers are available which is exclusively used for foliar application on plants (Vibhute CP, 1998) ${ }^{[14]}$. Here the ratio of $\mathrm{N}, \mathrm{P}, \mathrm{K}$ present in variable amount which is readily dissolve in water and ease in application also (Jayabal, A. et al., 1999) ${ }^{[5]}$. New flushes of leaves can effectively absorb the foliar feeders (Bonheure D and Willson KC, 1992) ${ }^{[2]}$. The growth and growth attributing characters as well as yield and yield attributing characters show significantly higher by application of 19:19:19 NPK foliar feeder @ 0.5\% (Siddheshwar B, 2013) ${ }^{[10]}$.

\section{Materials and Methods}

The present investigation was laid out during rabi season of 2018-19 and 2019-20 at Department of Floriculture and Landscaping, College of Agriculture, Odisha University of Agriculture and Technology, Bhubaneswar, Odisha. Geographically the experimental site is situated at $20^{\circ} 15^{\prime}$ North latitude and $85^{\circ} 15^{\prime}$ East longitude. Distance from Bay of Bengal is $63 \mathrm{kms}$ and this place is $25.5 \mathrm{~m}$ above the mean sea level (MSL). The average annual rainfall is $1577 \mathrm{~mm}$. The maximum temperature during the experiment was $32.2^{\circ} \mathrm{C}$ to $34.2^{\circ} \mathrm{C}$ and minimum temperature was $16.1^{\circ} \mathrm{C}$ to $22.1^{\circ} \mathrm{C}$. The relative humidity during the experiment was $48 \%$ to $95 \%$. From the chemical analysis of potting mixture it was seen that the soil was slightly acidic in reaction (6.38), high in organic carbon percentage $(0.055 \%)$, low in available Nitrogen $(150$ $\mathrm{kg} / \mathrm{ha})$, high in available Phosphorus $(258 \mathrm{~kg} / \mathrm{ha})$ and medium in available potassium (292.9 $\mathrm{kg} / \mathrm{ha})$. Potting mixture was prepared by taking garden soil, sand and FYM in 1:1:1 ratio. The seedlings of Coreopsis tinctoria was brought from the State Capital Nursery, Unit-2, Bhubaneswar. Transplanting was done late in the evening and immediately after transplanting lifesaving irrigation was given with the help of a rose cane. Vermicompost was applied after 7 days of transplanting to support the growth as a blanket application to all the treatments. With 7 treatments and 3 replications, the experiment was set out in completely randomized Design. There were 5 plants per treatment and the total number of plants comprises of 105 . The experiment was contained with the seven treatments viz. T1: 3ml/L Nanomax (4\% NPK), T2: 4ml/L Nanomax (4\% NPK), T3: 5ml/L Nanomax (4\% NPK), T4: 3g/L Polyfeed (19:19:19 NPK), T5: 4g/L Polyfeed (19:19:19 NPK), T6: 5g/L Polyfeed (19:19:19 NPK), T7: Control (No foliar feeder spray). The treatments were applied at 30, 45, 60 and 90 days after transplanting.

Observations were taken for vegetative parameters like plant height $(\mathrm{cm})$, number of primary branches, stem girth of plant $(\mathrm{cm})$, plant spread both in E-W and N-S direction $(\mathrm{cm})$; flowering parameters like days to first flowering (in days), duration of flowering (in days), longevity of intact flower (in days), number of flower per plant and flower quality parameters like diameter of flower $(\mathrm{cm})$, weight of individual flower(fresh) (g), weight of individual flower (dry) (g), weight of seeds from individual flower $(\mathrm{g})$.

\section{Result and Discussion}

The results obtained from the research work during 2018-19 and 2019-20 were pooled and described under following headings.

\section{Vegetative parameters}

The data presented in the table 1 revealed that the application of different levels of Nanomax (4\% NPK) and Polyfeed (19:19:19 NPK) differ significantly with respect to the vegetative parameters of Coreopsis tinctoria. Plants receiving the treatment T6 [5ml/L Polyfeed (19:19:19 NPK)] shows maximum values of vegetative parameters like plant height $(84.27 \mathrm{~cm})$, stem girth of plant $(2.90 \mathrm{~cm})$, number of primary branch (19), plant spread $(\mathrm{E}-\mathrm{W})(40.93 \mathrm{~cm})$, plant spread $(\mathrm{N}$ S) $(43.53 \mathrm{~cm})$. This may be due to the increased availability of nutrients by water soluble foliar feeders for rapid absorption of nutrients through leaf stomata by foliar application of Polyfeed (19:19:19 NPK) to growing plants, which may have increased chlorophyll formation, photosynthesis rate, development of dry matter and thus resulted in improved overall plant growth. These finding collaborate to the finding reported by Khawlhring et al. (2019) ${ }^{[6]}$ in Anthurium andreanum cv. Evita and El-Sayed et al. (2017) ${ }^{[3]}$ in Hibiscus rosa-sinensis.

Table 1: Influence of different levels of Nanomax (4\% NPK) and Polyfeed (19:19:19 NPK) on Vegetative parameters of Coreopsis tinctoria

\begin{tabular}{|c|c|c|c|c|c|}
\hline Treatments & $\begin{array}{c}\text { Plant height } \\
(\mathbf{c m}) * * *\end{array}$ & $\begin{array}{c}\text { Stem girth } \\
(\mathbf{c m}) * *\end{array}$ & $\begin{array}{c}\text { Number of } \\
\text { primary branch*** }\end{array}$ & $\begin{array}{c}\text { Plant spread } \\
(\mathbf{E}-W)(\mathbf{c m}) * * *\end{array}$ & $\begin{array}{c}\text { Plant spread } \\
(\mathbf{N}-\mathbf{S})(\mathbf{c m}) * *\end{array}$ \\
\hline T1: 3ml/L Nanomax (4\% NPK) & 81.87 & 2.76 & 15.27 & 36.93 & 42.2 \\
\hline T2: 4ml/L Nanomax (4\% NPK) & 82.73 & 2.83 & 16.73 & 37.73 & 41.33 \\
\hline T3: 5ml/L Nanomax (4\% NPK) & 83.47 & 2.84 & 17.4 & 39 & 42.13 \\
\hline T4: 3g/L (19:19:19 NPK) & 82 & 2.82 & 17.4 & 36.4 & 39.87 \\
\hline T5: 4g/L (19:19:19 NPK) & 83.33 & 2.87 & 17.93 & 38.8 & 41.13 \\
\hline T6: 5g/L (19:19:19 NPK) & 84.27 & 2.90 & 19 & 40.93 & 43.53 \\
\hline T7: Control (No fertilizer spray) & 78 & 2.64 & 13.67 & 34.07 & 36 \\
\hline S. E. (m) \pm & 0.7996 & 0.0221 & 0.5333 & 0.7437 & 0.9901 \\
\hline C.D. at 5\% & 1.9913 & 0.0550 & 1.3282 & 1.8520 & 2.4657 \\
\hline
\end{tabular}

**Highly Significant

\section{Flowering parameters}

There was significant difference among the treatments of water soluble foliar feeders with respect to the various flowering parameters. An appraisal of data presented in Table-2 indicated that among all treatment T6 [5g/L Polyfeed (19:19:19 NPK)] was noted performing better in case of flowering parameters like number of flower per plant (50.4) and longevity of intact flower (5.87 days). This may be due to the combined influence of the foliar feeder's nitrogen, phosphorus and potassium. In diverting food reserves to the site of differentiation of flower buds, nitrogen plays a critical role, resulting in more flowers per plant. Potassium, on the other hand, has also been involved in the acceleration of several enzymatic reactions, leading to a greater number of flowers per plant and a stronger survival of the intact flower. These findings were in accordance with the findings of Arvinder singh et al. (2013) ${ }^{[11]}$ in Carnation and Khawlhring C et al. (2019) ${ }^{[6]}$ in Anthurium.

It is clear from the presented data in table-2 that absolute control treatment T7 (No foliar feeder spray) recorded 
minimum days for first flowering as compared to other treatments. This is because of cessation of vegetative growth and which forces to flower earlier. However the application of higher level of nitrogen enhanced vegetative growth and delayed flowering. As the study are in accordance with Sreekanth et al. (2008) ${ }^{[13]}$.

From the perusal of the data presented in Table- 2 that the highest duration of flowering was observed in $\mathrm{T} 3[5 \mathrm{ml} / \mathrm{L}$ Nanomax (4\% NPK)] which is found to be statistically at par with T6 [5g/L Polyfeed (19:19:19 NPK)]. The flowering duration was higher when plants were treated with all three nutrients (Nitrogen, Phosphorus and Potassium), which might be due to synergistic effect of all three nutrient which means after full bloom the plant supported with $\mathrm{N}, \mathrm{P}$ and $\mathrm{K}$ was able to provide some food materials to the flower to sustain for a longer period. The findings are in line with those of Mohammadi and Azizi (2015) ${ }^{[8]}$ in chamomile (Matricaria recutita $\mathrm{L}$.) CV. Bodegold.

Table 2: Influence of different levels of Nanomax (4\% NPK) and Polyfeed (19:19:19 NPK) on Flowering parameters of Coreopsis tinctoria

\begin{tabular}{|c|c|c|c|c|}
\hline Treatments & $\begin{array}{c}\text { Number of flower } \\
\text { per plant** }\end{array}$ & $\begin{array}{c}\text { Days to first flowering (in } \\
\text { days)* }\end{array}$ & $\begin{array}{c}\text { Duration of flowering } \\
\text { (days)** }\end{array}$ & $\begin{array}{c}\text { Longevity of intact flower } \\
\text { (days)** }\end{array}$ \\
\hline T1: 3ml/L Nanomax (4\% NPK) & 40.73 & 37.47 & 80.73 & 5.2 \\
\hline T2: 4ml/L Nanomax (4\% NPK) & 43.8 & 38.33 & 81.07 & 5.53 \\
\hline T3: 5ml/L Nanomax (4\% NPK) & 45.73 & 39.2 & 81.8 & 5.53 \\
\hline T4: 3g/L (19:19:19 NPK) & 42.2 & 38.8 & 80.33 & 5.53 \\
\hline T5: 4g/L (19:19:19 NPK) & 47.67 & 40 & 80.27 & 5.8 \\
\hline T6: 5g/L (19:19:19 NPK) & 50.4 & 39.93 & 81.73 & 5.87 \\
\hline T7: Control (No fertilizer spray) & 30.33 & 36.8 & 66.07 & 4.87 \\
\hline S. E. (m) \pm & 1.0201 & 0.7077 & 0.6983 & 0.1208 \\
\hline C.D. at 5\% & 2.5405 & 1.7626 & 1.7390 & 0.3009 \\
\hline
\end{tabular}

*Significant **Highly Significant

\section{Flower quality parameters}

There was significant difference among the different levels of Nanomax (4\% NPK) and Polyfeed (19:19:19 NPK) with respect to the various flower quality parameters. Result of the present investigation presented in Table- 3 reveals that the treatment T6 [5g/L Polyfeed (19:19:19 NPK)] showing better results among the rest of the treatments in case of flower quality parameters like diameter of flower $(4.82 \mathrm{~cm})$, weight of individual flower (fresh) (2.36 g), weight of individual flower (dry) $(0.64 \mathrm{~g})$ and weight of seeds from individual flower (0.19). The increase in flower diameter may be attributable to the fact that increased carbohydrate assimilation contributed to increased vegetative growth attributable to the balanced application of fertiliser through the foliar feeder. When translocated to reproductive organs, these carbohydrates underwent hydrolysis and were converted into reduced sugar, which eventually helped increase the size of the flower. The data recorded on the fresh and dry weight of flowers per plant and weight of seeds from single flower as influenced by water soluble foliar feeder. Nitrogen, phosphorus and potassium balance doses can be responsible for increasing vegetative growth there by resulting in increased photosynthesis activity at the source that can be used at the sink and increasing the fresh and dry flower weight as well as the weight of individual flower seeds. The above findings are in agreement with the findings of Majeed K. Abbas and Ali Sabah Ali (2011) ${ }^{[1]}$ in Hibiscus sabdariffa L, Saira Shabeer Khosa et al. (2011) ${ }^{[7]}$ in gerbera, Arvinder singh et al. (2013) ${ }^{[11]}$ in carnation and Khawlhring, C. et al. $(2019)^{[6]}$ in anthurium.

Table 3: Influence of different levels of Nanomax (4\% NPK) and Polyfeed (19:19:19 NPK) on Flower quality parameters of Coreopsis tinctoria

\begin{tabular}{|c|c|c|c|c|}
\hline Treatments & $\begin{array}{c}\text { Diameter of } \\
\text { flower }(\mathbf{c m}) * *\end{array}$ & $\begin{array}{c}\text { Weight of individual flower } \\
\text { (fresh) (in g)** }\end{array}$ & $\begin{array}{c}\text { Weight of individual } \\
\text { flower (dry) (in g) } * *\end{array}$ & $\begin{array}{c}\text { Weight of seeds from } \\
\text { individual flower (in g) } * *\end{array}$ \\
\hline T1: 3ml/L Nanomax (4\% NPK) & 4.46 & 1.92 & 0.56 & 0.16 \\
\hline T2: 4ml/L Nanomax (4\% NPK) & 4.52 & 2.07 & 0.58 & 0.16 \\
\hline T3: 5ml/L Nanomax (4\% NPK) & 4.77 & 2.14 & 0.61 & 0.2 \\
\hline T4: 3g/L (19:19:19 NPK) & 4.53 & 2.19 & 0.61 & 0.17 \\
\hline T5: 4g/L (19:19:19 NPK) & 4.79 & 2.18 & 0.61 & 0.18 \\
\hline T6: 5g/L (19:19:19 NPK) & 4.82 & 2.36 & 0.64 & 0.19 \\
\hline T7: Control (No fertilizer spray) & 4.23 & 1.83 & 0.49 & 0.14 \\
\hline S. E. (m) & 0.0879 & 0.0520 & 0.0135 & 0.0081 \\
\hline C.D. at 5\% & 0.2189 & 0.1297 & 0.0336 & 0.0200 \\
\hline
\end{tabular}

**Highly Significant

\section{Conclusion}

On the basis of the findings of the present investigation, it may be concluded that there was significant difference in between the different levels of Nanomax (4\% NPK) and Polyfeed (19:19:19 NPK). Among the different concentration levels of water soluble foliar feeders on Coreopsis tinctoria, treatment T6 (5g Polyfeed (19:19:19 NPK)/L) sprayed at different growth stages of plant found to be the best treatment with respect to various vegetative parameters, flowering parameters, flower quality parameters.

\section{References}

1. Abbas MK, Ali AS. Effect of foliar application of NPK on some growth characters of two cultivars of Roselle (Hibiscus sabdariffa L.). American Journal of Plant Physiology, 2011; 6(4):220-227.

2. Bonheure D, Willson KC. Mineral nutrition and fertilizers in Tea. Springer, Dordrecht, 1992, 269-329.

3. El-Sayed AEGA, Darwesh MA, Nabih A, Soliman MM. Effect of different types of fertilization on morphological characters and chemical constituents of three cultivars of Hibiscus rosa-sinensis plants. Zagazig Journal of Agricultural Research. 2017; 44(1):87-102. 
4. Garcia LR, Hanway JJ. Foliar Fertilization of Soybeans during the Seed-filling Period 1. Agronomy Journal. 1976; 68(4):653-657.

5. Jayabal A, Revathy M, Saxena MG. Effect of foliar nutrition on nutrient uptake pattern in soybean. Andhra Agriculture Journal. 1999; 46:243-244.

6. Khawlhring C, Patel GD, Lalnunmawia F. Productivity and quality of Anthurium andreanum influenced with growing conditions and fertilizers. Journal of Applied and Natural Science. 2019; 11(2):240-244.

7. Khosa SS, Younis A, Rayit A, Yasmeen S, Riaz A. Effect of foliar application of macro and micro nutrients on growth and flowering of Gerbera jamesonii L. American Eurasian Journal of Agriculture and Enviromental Science. 2011; 11:736-757.

8. Mohammadi S, Azizi M. Effects of different levels of Farmax ${ }^{\circledR}$ nano fertilizer and foliar spraying time on growth and effective substance of German chamomile (Matricaria recutita). Journal of Horticultural Science. 2015; 28(4):50.

9. Qureshi A, Singh DK, Dwivedi S. Nano-fertilizers: a novel way for enhancing nutrient use efficiency and crop productivity. International Journal of Current Microbiological Applied Science, 2018; 7:3325-3335.

10. Siddheshwar BD. Effect of foliar spray of water soluble fertilizers on growth, yield and quality of wheat (Doctoral dissertation, Mahatma Phule Krishi Vidyapeeth, Rahuri.), 2013.

11. Singh A, Sharma BP, Gupta YC, Dilta BS, Laishram N. Response of carnation (Dianthus caryophyllus) cv Master to water soluble fertilizer Sujala (19: 19: 19 NPK). The Indian Journal of Agricultural Sciences. 2013; 83(12).

12. Smith EB, Parker HM. A biosystematic study of Coreopsis tinctoria and C. cardaminefolia (Compositae). Brittonia. 1971; 23(2):161-170.

13. Sreekanth P, Padma M, Chandrasekhar R, Madhulety TY. Effect of planting time, spacing and nitrogen levels on growth of African marigold (Tagetes erecta L.) cv. Sierra orange. Orissa Journal of Horticulture. 2008; 36(1):69-7

14. Vibhute CP. A Process for Manufacturing Complex Solid and Liquid Completely Water Soluble Fertiliser. Fertiliser News. 1998; 43:63-63. 